\title{
Apakah Benar Penderita Depresi Selalu Sulit Melakukan Regulasi Emosi?
}

\author{
Wendio Angganantyo ${ }^{1}$, Zainal Abidin ${ }^{2}$ \\ Fakultas Psikologi, Universitas Padjadjaran \\ Jl. Raya Bandung-Sumedang, Hegarmanah, Jatinangor, Kabupaten Sumedang, Jawa Barat, Indonesia, 45363 \\ wendinantyo@gmail.com
}

\begin{abstract}
Abstrak
Banyak penelitian yang menyatakan bahwa penderita depresi identik dengan adanya kesulitan dalam meregulasi emosi, namun dari hasil screening pada 64 partisipan, ternyata ditemukan penderita depresi yang tidak sulit melakukannya. Penelitian ini bertujuan untuk menggambarkan hal-hal yang membuat penderita depresi tidak sulit dalam meregulasi emosi. Untuk mendapatkan gambaran terkait kasus tersebut, digunakan metode studi kasus dengan pendekatan komparatif. Partisipan dalam penelitian ini adalah dua penderita depresi severe dimana satu orang tidak sulit melakukan regulasi emosi (subjek pertama) dan satu orang sulit meregulasi emosinya (subjek kedua) sebagai pembanding. Pengambilan data dilakukan menggunakan teknik wawancara semi terstruktur yang berbasis pada dimensi konstruk Difficulties of Emotion Regulation Scale (DERS) untuk melihat gambaran regulasi emosi dan wawancara tidak terstruktur untuk melihat gambaran kondisi depresi. Hasil wawancara yang dianalisis secara thematic menunjukkan dua faktor yang membedakan sulit atau tidaknya kedua subjek meregulasi emosi, yaitu penyebab depresi dan mekanisme regulasi emosi. Penyebab depresi subjek pertama lebih berpusat pada konflik intrapersonal sedangkan pada subjek kedua lebih menekankan pada hubungan interpersonal. Subjek pertama memiliki mekanisme regulasi emosi yang terstruktur yakni relaksasi yang kemudian dilanjutkan dengan usaha untuk berpikir logis serta berfokus pada solusi, sedangkan subjek kedua hanya mengandalkan ekspresi agresi tanpa memiliki mekanisme regulasi emosi yang terstruktur.
\end{abstract}

Kata Kunci: Kesulitan Regulasi Emosi; Depresi; Intrapersonal; Interpersonal; Studi Kasus

\begin{abstract}
Many research shows a strong correlation between depression and difficulties of emotion regulation, yet depression individual without any intricacy of that has been found from the screening of 64 participants. This study aims to depict the things that make depressed individual has no difficulties in regulating emotions. Concerning the profound picture of the case, we used the case study method with a comparative approach. Two severe depression individuals with no difficulties $\left(1^{\text {st }}\right.$ subject) and with difficulties $\left(2^{\text {nd }}\right.$ subject) undertaking emotion regulation were recruited to be compared. Data gathered by semi-structured interview based on the dimensional construct of Difficulties of Emotion Regulation Scale (DERS) to perceive the overview of emotion regulation. Unstructured interviews were used to investigate the depression conditions. Results yielded of the thematic analysis indicate two factors that distinguish their adversity in regulating their emotion; depression etiology and emotion regulation mechanism. The cause of depression in the first subject mainly intensified on intrapersonal conflict whilst the other inclined to interpersonal relationship. The emotion regulation mechanism on the first subject is a sequential mechanism that consists of relaxation method, logical thinking, and solutionfocused. On the contrary, the second subject relies on the expression of impulse aggression with no structured mechanism.
\end{abstract}

Keywords: Difficulties of Emotion Regulation, Depression, Intrapersonal, Interpersonal; Case Study

\section{PENDAHULUAN}

Depresi merupakan salah satu jenis gangguan jiwa yang kerap kali tidak disadari baik oleh penderita itu sendiri maupun oleh orang-orang disekitar penderita. Dalam ranah global, penderita depresi diperkirakan mencapai 322 juta jiwa (World Health Organisation, 2017). Di Indonesia, prevalensi penderita depresi yang dikategorikan dalam gangguan mental emosional mencapai 14 juta orang atau sekitar $6 \%$ dari total seluruh jumlah penduduk dimana prevalensi tersebut bervariasi antar provinsi (Badan Penelitian dan Pengembangan Kesehatan, 2013). Dari 
sekian banyak daerah di Indonesia, Jawa Barat berada pada urutan kedua tertinggi gangguan mental emosional, yaitu 9.3\% (Badan Penelitian dan Pengembangan Kesehatan, 2013). Tingginya angka penderita depresi akan menjadi beban negara yang menyebabkan penurunan kualitas sumber daya manusia dan berpotensi menambah angka kematian akibat aksi bunuh diri. Terlebih jika hal itu terjadi pada kelompok usia produktif seperti mahasiswa. Hingga kini, bermacam-macam teknik dan metode yang mengusung aspek biopsikososiokultural telah banyak digunakan untuk mengatasi depresi. Beberapa orang mampu pulih dan kembali dalam kondisi seperti sedia kala atau bahkan menjadi semakin meningkat kualitas hidupnya. Namun tidak sedikit juga yang mengalami relapse setelah pulih dari depresi, bahkan presentase terjadinya relapse mencapai $90 \%$ bagi mereka yang memiliki dua episode atau lebih (Williams, Crane, Barnhofer, Van der Goes, \& Segal, 2006).

Taraf pemulihan depresi sangat berkaitan erat dengan faktor lain yang berada dalam level internal individu. Salah satu faktor tersebut adalah ketidakmampuan seseorang dalam meregulasi emosi yang menyebabkan kondisi depresi menjadi semakin parah atau menetap dalam jangka waktu lama (Joormann \& Gotlib, 2010). Regulasi emosi adalah proses atau cara yang dimiliki seseorang untuk mengontrol emosi yang dimiliki, untuk mengetahui kapan dan bagaimana emosi tersebut dialami dan diekspresikan (Gross J.J, 2014). Emosi yang umumnya tidak mampu diregulasi dengan baik oleh individu depresi adalah emosi negatif (Millgram, Joormann, Huppert, \& Tamir, 2015). Hal ini adalah salah satu penyebab utama durasi kesembuhan depresi menjadi semakin lama atau bahkan menetap dan menjadi kronis (Compare, Zarbo, Shonin, Van Gordon, \& Marconi, 2014; Loeffler, Radke, Habel, Ciric, Satterthwaite, Schneider, \& Derntl, 2018). Kesulitan regulasi emosi tersebut diperparah oleh adanya kecenderungan untuk mengaitkan hal yang bersifat negatif dalam kehidupan dengan internal attribution, sedangkan hal positif cenderung dikaitkan dengan external attribution (Loeffler dkk, 2018). Tidak jarang kedua attribution yang dilakukan lebih mengarah kepada catastrophising (Angell, 2017) dan ruminasi (Joormann \& Gotlib, 2010). Akibatnya, regulasi emosi yang dilakukan semakin mengarahkan mereka pada kesedihan atau emosi negatif yang terus mendalam (LeMoult \& Gotlib, 2018; Millgram, Joormann, Huppert, \& Tamir, 2015). Jika dilihat dari perspektif fisiologis, amygdala yang berfungsi sebssagai pusat pengendalian emosi pun menjadi sangat peka dan responsif akan stimulus emosi negatif pada individu penderita depresi (Kalia, 2005; Leppänen, 2006).

Meskipun berbagai bukti ilmiah banyak menunjukkan keterkaitan kuat antara depresi dan kesulitan regulasi emosi (Ehring, Tuschen-Caffier, Schnülle, Fischer, \& Gross, 2010; James J. Gross \& Jazaieri, 2014; Joormann \& Gotlib, 2010; Troy, Shallcross, \& Mauss, 2013; Whitmer \& Gotlib, 2012), pada kenyataannya terdapat penderita depresi yang bahkan tidak kesulitan untuk meregulasi emosinya setelah peneliti melakukan screening. Berdasarkan hasil screening yang dilakukan pada 64 mahasiswa di Universitas Padjadjaran menggunakan DERS (Difficulties of Emotion Regulation Scale) yang dikembangkan oleh Gratz dan Roemer (2004) untuk melihat secara lebih spesifik derajat kesulitan seseorang dalam meregulasi emosi dan PHQ-9 untuk melihat tingkat depresi, terdapat satu partisipan yang tidak kesulitan meregulasi emosi terlepas dari tingkat depresi severe yang dialami. Karena temuan ini berbeda dengan literatur-literatur yang menyatakan bahwa individu depresi hampir dipastikan sulit meregulasi emosinya, maka temuan ini cukup unik dan cukup menarik untuk ditelusuri lebih jauh. Oleh karena itu, tujuan penelitian ini adalah untuk mendapatkan gambaran mengenai bagaimana individu depresi tidak kesulitan meregulasi emosinya dengan cara membandingkan gambaran regulasi emosi pada individu depresi dengan kesulitan regulasi emosi yang tinggi. 


\section{METODE}

Penelitian ini menggunakan metode studi kasus (Yin, 2018) dengan pendekatan komparatif. Perbandingan dalam penelitian ini tidak hanya bertujuan untuk mendapatkan pemahaman terkait suatu kasus, melainkan juga untuk menekankan bagaimana kasus tersebut tidak terjadi pada subjek lainnya, sesuai dengan Lindsay (2019a). Lindsay (2019b) membagi lima pendekatan komparatif yang bisa digunakan untuk penelitian kualitatif dimana salah satunya adalah membandingkan subjek dengan fenomena atau kasus berbeda. Subjek dengan kasus berbeda yang akan dijadikan perbandingan dalam penelitian ini adalah penderita depresi dengan kesulitan regulasi emosi. Kedua subjek belum pernah mendapatkan penanganan profesional (psikolog atau psikiater) sebelumnya. Screening dilakukan kepada 64 mahasiswa/i aktif menggunakan skala DERS yang telah diadaptasi ke dalam bahasa Indonesia untuk mengukur tingkat kesulitan regulasi emosi. Sedangkan untuk melihat mahasiwa/i mana yang memiliki depresi serta tingkat keparahannya, peneliti menggunakan skala PHQ-9. Screening dilakukan menggunakan Google Form dan dikerjakan oleh seluruh responden melalui perangkat digital masing-masing. Hasil screening memperlihatkan adanya 15 orang yang tidak mengalami depresi serta tidak kesulitan meregulasi emosi, 26 orang mengalami depresi ringan yang sembilan diantaranya cukup sulit meregulasi emosi, dan 13 orang menunjukkan adanya depresi sedang dimana enam orang diantaranya tampak sulit meregulasi emosi. Kemudian enam orang ditemukan pada kondisi depresi sedang ke berat dan hanya satu orang diantara jumlah tersebut yang tidak kesulitan melakukan regulasi emosi. Terakhir, empat orang terlihat mengalami depresi berat atau severe dimana satu diantaranya tidak sulit meregulasi emosi.

\section{Pengambilan Sampel dan Data}

Sebanyak 64 mahasiswa/ baik S1 dan S2 telah berpartisipasi dalam screening. Dari screening tersebut, didapatkan empat subjek yang terindikasi depresi dalam level yang sama (severe). Dari empat subjek tersebut, hanya tiga orang yang bersedia diwawancarai lebih lanjut dimana salah satunya adalah subjek yang tidak kesulitan meregulasi emosi. Pengambilan data dilakukan menggunakan teknik wawancara tatap muka, yakni wawancara semi terstruktur untuk melihat gambaran perbedaan regulasi emosi dan wawancara tidak terstruktur untuk melihat gambaran kondisi depresi pada kedua subjek yang mungkin mempengaruhi bagaimana mereka meregulasi emosi. Panduan interview semi terstruktur dibuat berdasarkan konstruk dimensi dan teori yang ada dalam DERS untuk selanjutnya dikembangkan menjadi pertanyaan yang lebih mendalam. Dimensi tersebut adalah awareness, clarity, nonacceptance, strategies, impulse, dan goals. Sebagai contoh, peneliti menanyakan "Bisa anda ceritakan apa yang biasanya anda lakukan ketika merasakan emosi negatif seperti marah, kesal, sedih, dan lainnya?" untuk melihat dimensi strategies. Kedua subjek setuju untuk mengikuti penelitian ini yang direpresentasikan dengan pengisian lembar kesediaan atau informed consent. Durasi interview adalah 63 menit untuk subjek pertama. Sedangkan waktu yang dibutuhkan untuk subjek kedua adalah 32 menit. Interview dilakukan di dua hari yang berbeda dan proses intervew direkam menggunakan perekam seluler.

\section{Analisis Data}

Setelah interview selesai, transkrip wawancara kedua subjek yang telah direkam kemudian disalin dalam bentuk tulisan. Transkrip tersebut berisi pertanyaan dari peneliti dan jawaban yang diberikan oleh kedua subjek. Analisis thematic dilakukan pada transkrip ini. Jawaban subjek diberi kode berdasarkan tema yang sesuai. Setelah beberapa pernyataan dikelompokkan, dilakukanlah tahap axial coding untuk menspesifikkan lagi tema yang terkandung dalam transkrip. Langkah terakhir adalah semua tema yang telah dikategorikan tersebut dikelompokkan lagi dalam beberapa istilah; selective code. Selanjutnya, dalam penulisan quote 
oleh subjek, keterangan tema diberikan pada setiap kutipan percakapan subjek menggunakan selective code tersebut.

\section{HASIL}

\section{Subjek Pertama (AA)}

\section{Gambaran Kondisi Depresi}

Depresi subjek yang tergolong severe menjadi salah satu fokus dalam penelitian ini. Peneliti sengaja memberikan gambaran depresi subjek sebagai data tambahan dan bahan pertimbangan untuk menjelaskan secara lengkap dinamika dari kesulitan regulasi emosi subjek pertama dalam kaitannya dengan depresi yang membuatnya menjadi kasus unik, yaitu kemampuan regulasi emosi yang cukup baik terlepas dari depresi severe yang diderita. Oleh karena itu, peneliti akan mendeskripsikan depresi yang dialami oleh subjek pertama.

\section{Sexual Orientation (Lesbian)}

Meskipun baru terbuka mengenai hal ini di penghujung wawancara, subjek terbilang cukup terbuka ketika menjawab semua pertanyaan peneliti. Dalam wawancara, subjek mengaku dirinya mengakui tertarik pada sesama jenis dimulai ketika mendapatkan informasi dari internet bahwa memang terdapat individu-individu yang menyukai jenis kelamin yang sama. Pengakuan ini pun baru muncul ketika peneliti bertanya tentang masalah keluarga seperti yang tercermin dari pernyataannya berikut ini.

"Sebenernya keluarga baik-baik aja sih, lebih ke diri saya masalahnya. Emmm nangis nih ntar saya hehehe. (terdiam cukup lama) Saya LGBT."

Pilihan subjek untuk bersikukuh pada orientasi seksualnya ini menyebabkan konflik internal yang berperan besar dalam membentuk depresinya. Konflik tersebut menyebabkan beberapa masalah seperti Nonsuicidal Self Injury, Suicidal Ideation, dan Family Rejection.

\section{Nonsuicidal Self Injury (NSSI)}

Tindakan menyakiti diri sendiri ini sudah dilakukan oleh subjek sejak SMP kelas 2, tepat ketika masa dimana subjek mengetahui bahwa dirinya adalah seorang lesbian. Bentuk dari NSSI yang dilakukan adalah menyayat-nyayat bagian tubuh sendiri dengan menggunakan benda tajam. Pada kasus ini, sayatan ditujukan pada tangan dan kaki seperti yang tergambar pada pernyataan subjek di bawah ini.

"Jadi waktu saya SMP kelas 2, saya sering self-harm dengan cara cutting, di bagian tangan sama kaki. Saya sadar waktu saya melakukan itu, tapi ga tau apa yang sakit. Ga tau emosi apa yang saya rasakan, pokoknya sakit aja. Tapi kalo saya marah atau sedih saya ga pernah melakukan itu. Jadi ada sesuatu dalam diri saya yang rasanya sakit, sakiit banget. Tapi saya ga tau itu apa." (NSSI)

Dari pernyataan di atas didapatkan pula suatu fakta bahwa subjek tidak mengetahui apa yang sebenarnya membuat dirinya merasa kesakitan sehingga sensasi tersebut dimanifestasikan pada sensasi rasa sakit yang nyata, yaitu luka sayatan. Namun, subjek tidak hanya melakukan tindakan tersebut tanpa diiringi oleh tindak lanjut tertentu. Setiap NSSI dilakukan, subjek selalu mencatat tanggal dimana dirinya melakukan aksi tersebut. Hal ini ia lakukan sebagai wujud dokumentasi untuk mengetahui berapa kali tepatnya NSSI dilakukan oleh dirinya (selfmonitoring) sebagaimana yang tertulis pada jawaban subjek disini;

"Ga pernah ngitung sih, tapi kalo saya cutting biasanya saya tanggalin. Jadi di tanggal ini saya cutting. Tapi 3 bulan ini ga pernah kok." (Self-Monitoring) 


\section{Suicidal Ideation}

Depresi dengan tingkat yang severe umumnya juga diiringi dengan munculnya pemikiran untuk melancarkan aksi bunuh diri, termasuk pada subjek AA. Melintasnya ide untuk bunuh diri selalu muncul ketika subjek berada dalam situasi apapun selama situasi tersebut memiliki potensi untuk membunuh atau menyakiti dirinya secara fisik. Sebagai contoh, ketika subjek berjalan di pinggir jalan raya, ide untuk menabrakkan diri ke arah kendaraan yang melintas selalu mendominasi pikirannya. Tidak hanya itu, ketika subjek menuruni tangga di kampus, ide untuk menjatuhkan diri dari tangga juga selalu muncul. Berikut pernyataan subjek terkait hal ini;

"Iya. Tiap saat. Bahkan saya jalan di pinggir jalan ini barusan aja saya udah mikir mau nabrakin diri saya." (Suicidal Ideation)

"Emm ga pernah sih. Tapi kalo hampir melakukan pernah. Kayak kemarin-kemarin itu saya turun tangga di kampus, saya udah mikir mau menjatuhkan diri dan hampir melakukan itu. Tapi untungnya ga saya lakukan, sebabnya apa ga saya lakukan saya ga tau. Dan yaa itu tadi yang saya bilang bahkan untuk hidup sampe sekarang aja saya takjub hehe." (Suicidal Ideation)

\section{Family Rejection}

Salah satu masalah yang membebani pikiran subjek adalah jika dirinya ditolak oleh keluarganya, khususnya orang tua, apabila mereka mengetahui identitas lesbian subjek. Beban pikiran ini didasari oleh adanya nilai-nilai dan budaya agama yang sedikit radikal pada keluarga subjek. Akibatnya, subjek merasa takut dan cenderung tidak nyaman ketika berada di rumah bersama keluarga. Berikut ini adalah pernyataan subjek;

"Belum. Saya belum bilang ke keluarga saya. Tapi saya yakin mereka ga akan bisa menerima. Kecuali adik saya yang pertama itu sih. Karena orang tua saya itu keras. Apalagi ayah. Islamnya yang cukup radikal. Jadi ya bisa dibayangkan kalo saya mengaku LGBT responnya akan seperti apa. Saya ga dianggap anak mungkin.” (Family Rejection)

\section{Gambaran Regulasi Emosi}

\section{Strategies (S)}

Dalam strategi (S) yang digunakan oleh subjek, diperoleh tiga metode yaitu; relaxation, logical thinking, dan solution-focused. Ketiga metode tersebut berjalan beriringan yang membentuk suatu mekanisme subjek dalam meregulasi emosinya. Berikut skema mekanisme strategi regulasi emosi yang digunakan;

\section{Relaxation}

Ketika mengalami atau mendapati situasi emosional, subjek berusaha untuk menenangkan diri terlebih dahulu dengan melakukan relaksasi. Relaksasi dilakukan dengan cara mencari tempat duduk, berusaha duduk, kemudian mengambil nafas panjang, setelah itu menghembuskannya. Teknik pernafasan tersebut dilakukan berulang kali hingga subjek menjadi rileks. Dalam transkrip, subjek menjelaskan relaksasi yang dimaksud olehnya sebagai berikut;

"Jadi saya biasanya kalo ngerasa seperti itu tuh diem dulu, duduk, nenangin diri dulu, tarik nafas dalam-dalam terus dikeluarin dan teratur." (Relaxation)

Dengan melakukan relaksasi pernafasan tersebut, otot-otot dalam tubuh akan meregang, irama jantung menjadi teratur, dan darah menjadi lebih lancar mengalir ke seluruh tubuh 
dimana proses fisiologis ini menciptakan perasaan tenang dan membuat aspek kognitif terlepas dari intervensi emosi. Oleh karena itu, subjek mampu berpikir logis setelah relaksasi dilakukan.

\section{Logical Thinking}

Setelah relaksasi, subjek berpikir secara logis mengenai apa yang dirasakannya dan efeknya terhadap apa yang menjadi fokusnya. Sebagaimana yang dikatakan oleh subjek di bawah ini;

"Saya ngerasa kayak marah tapi saya ngerasa marah saya tuh bakal sia-sia gitu. Jadi marah sih marah, tapi marah buat apa. Jadi ujungnya ngerasa kayak apa yang saya rasakan jadi sia-sia gitu. Ga bikin masalah selesai juga." (Logical Thinking)

"Jadi fokus ke gimana supaya beres, karena saya kesel, saya marah juga buat apa ga membantu masalahnya beres juga." (Logical Thinking)

Melalui pemikiran logis mengenai emosi yang dirasakan, subjek mampu menjernihkan pikiran untuk melihat stimulus emosi dengan lebih objektif. Secara tidak disadari, koneksi antara tubuh dan pikiran (mind-body connection) melalui relaksasi dan logical thinking berhasil diselaraskan oleh subjek.

\section{Solution Focused}

Tahap ini dihayati oleh subjek sebagai langkah final dalam meregulasi emosi. Dalam tahap ini subjek tidak lagi berfokus pada emosi yang dirasakan, melainkan solusi dari stimulus emosi yang didapatkan atau dialami. Tahap ini bahkan disampaikan oleh subjek sebanyak 3 kali pada konteks pertanyaan yang berbeda, seolah menunjukkan penekanan. Berikut pernyataan subjek:

"Eee, yang saya pikirkan..karena saya udah lama juga udah ga merasa seperti itu, yang saya pikirkan kalo misal saya lagi marah, saya berpikir setelah ini apa yang harus saya lakukan. Kayak saya marah sama adik saya, saya mikir harus ngapain, ini adik saya harus diapain, saya harus ngomong apa sama dia. Terus habis itu kalo udah beres baru saya bisa mikir kayak main game, seneng-seneng. Jadi saya mesti ngurusin sumber dari emosi saya dulu sih." (Solution-focused)

"Setelah itu baru saya mikir apa yang bisa saya lakukan buat mengatasi ini." (Solutionfocused)

"Terus baru mikir penyelesaiannya gimana. Jadi fokus ke gimana supaya beres, karena saya kesel, saya marah juga buat apa ga membantu masalahnya beres juga." (Solutionfocused)

\section{Impulse (I)}

Pada dimensi ini, subjek menggunakan motoric expression untuk menyalurkan impulsifitasnya ketika sedang merasakan emosi negatif. Ekspresi tersebut berupa aktivitas menulis dan mencoret-coret. Tulisan yang dibuat oleh subjek tidak spesifik mengarah kepada bentuk tulisan tertentu yang bersifat konkret (e.g. diary, novel, dan lainnya), tetapi berupa tulisan apapun. Bahkan coretan pun juga tidak spesifik, seperti yang tergambar pada pernyataan subjek di bawah ini;

"Biasanya sih kalo saya emosi, saya suka nulis, tapi bukan seperti diary gitu. Ya apa aja ditulis. Terus saya juga suka nyoret-nyoret. Lebih kayak tangan saya itu perlu ada kerjaan gitu." (Inclination of Aggression)

Pada kalimat terakhir, subjek mengesampingkan jenis tulisan dan coretan yang dibuat serta menekankan ekspresi gerakan tangan yang harus dilakukan untuk mengontrol impulsifitas. Hal 
ini mengisyaratkan bahwa subjek sebenarnya butuh untuk menyalurkan agresinya ketika merasakan emosi negatif, namun subjek memilih untuk memanifestasikan agresi tersebut kepada aktivitas yang tidak bersifat destruktif walau masih tergolong abstrak.

Hasil ini diperkuat oleh adanya pengalaman agresi yang pernah dilakukan oleh subjek dalam bentuk verbal kepada teman-teman pria dan gurunya ketika masih duduk di bangku SMP. Ditambah lagi subjek juga mengakui agresivitasnya ketika ia menceritakan pengalaman konflik dengan teman dekatnya;

"Pernah sih sama temen deket. Waktu itu dia lagi sebel sama saya karena saya pacaran dan dia ga suka sama pacar saya. Jadi ya dia marah gitu terus kita berantem dan adu mulut di chat. Seperti yang saya bilang tadi, saya paling ga suka kalo privasi saya dilangkahin ................. hahaha kalo secara langsung saya mungkin udah jotos-jotosan karena saking sebelnya." (verbal aggression \& inclination of aggression)

\section{Goals (G)}

Blurred Long-term Goals merupakan pengalaman subjektif yang ditemukan dalam transkrip wawancara dengan subjek terkait dimensi ini. Subjek menjelaskan tujuan jangka panjangnya secara abstrak, bias, dan dalam arti yang sangat luas seperti;

"Ga ada kayaknya. Karena menurut saya tujuan hidup itu beda sama cita-cita, jadi kalo tujuan hidup saya ga ada. Tapi kalo apa yang ingin saya capai. Ya seputar isu yang tadi. Hidup saya saat ini berkutat dengan isu yang saya bilang tadi. Terdengar klise sih, tapi saya ingin menjadi bagian dari apa yang bisa membuat kehidupan yang lebih baik buat orang-orang eee karena concern saya diskriminasi jadi ya membuat kehidupan tanpa diskriminasi." (Blurred Long-term Goal)

Oleh karena tidak adanya kejelasan tujuan jangka panjang, subjek hanya berfokus pada tujuan jangka pendek yang bersifat temporer. Ketika meregulasi emosinya, tujuan jangka pendek ini berkorelasi dengan dua dimensi yang telah dijelaskan sebelumnya yaitu strategi dan impulse.

\section{Awareness (A), Clarity (C), dan Nonacceptance (N)}

Pada ketiga dimensi ini, subjek ternyata mampu menyadari jika dirinya sedang mengalami dan merasakan emosi negatif. Subjek bahkan mampu membedakan jenis-jenis emosi negatif yang dirasakan ketika berada dalam situasi emosional dan sanggup mengidentifikasi perasaan atau emosi negatif apa yang paling dominan dirasakan oleh dirinya, yaitu perasaan depressed. Dari kesadaran dan kemampuannya dalam membedakan emosi negatif yang dirasakan, subjek menerima dan mengakui semua emosi tersebut tanpa diiringi oleh perasaan bersalah, malu, dan kecewa. Seperti yang terlihat pada jawaban subjek berikut ini;

"Yaa kalo saya mengaku ke orang lain dan membuat orang lain tau kalo saya marah, saya sedih, saya kecewa sih enggak. Tapi kalo ke diri sendiri iya, kayak oke saya ngerasa marah, saya ngerasa sedih, tapi untuk tindakan selanjutnya sih enggak." (Emotional Acceptance)

"Ya kayak gitu sih kalo saya lagi marah sama orang lain, biasanya saya suka marah sendiri kayak ih apa sih kok gini gini gini dan biasanya sampe saya ada kegiatan yang bisa bikin distraksi dan kalopun ga ada saya bakal nyari kerjaan lain." (Self-talk)

“Apa ya, ya kalo saya pingin nangis ya nangis, kalo saya mau ngapa-ngapain ya saya ladenin aja dulu kayak nangis, tidur, makan, ya macem-macem hahaha tapi yang paling sering ya nangis sih. Saya ga ada masalah dengan nangis, menurut saya ga ada yang salah dengan nangis, ya saya biasanya nangis aja." (Emotional Expression) 
Dari data diatas terlihat pengakuan dan keluhan subjek diekspresikan dalam bentuk selftalk. Selain itu, terlihat juga ketiadaan tindakan nyata terhadap emosinya yang cenderung ditekan secara sadar (supresi) untuk kemudian dialihkan dengan melakukan aktivitas lain. Jika subjek tidak menemukan aktivitas lain, supresi perasaan tersebut diekspresikan dengan cara menangis. Mekanisme ini nampaknya digunakan oleh subjek ketika berhadapan dengan stimulus emosi yang disebabkan oleh orang lain yang bukan merupakan significant others.

\section{Subjek Kedua (A)}

\section{Gambaran Kondisi Depresi}

Seperti pada subjek sebelumnya, subjek kedua juga memiliki depresi yang masuk dalam kategori severe berdasarkan kategori PHQ-9. Pada subjek ini, permasalahan utama disebabkan oleh hubungan interpersonal baik dalam keluarga maupun lingkungan sosial yang tidak harmonis. Aktivitas NSSI juga ditemukan meskipun sedikit berbeda dengan subjek pertama. Penemuan yang paling signifikan pada subjek kedua ini adalah adanya suicidal action yang pernah dilakukan meskipun pada akhirnya gagal merenggut nyawa subjek.

\section{Interpersonal Relation}

"Aku udah dijauhin sama sahabat aku. Jadi aku kan waktu awal kuliah punya sahabat gitu ya. Cuman entah kenapa dia ngga mau lagi sama aku gitu." (Interpersonal Relation)

"He'em, kelas yang sama. Pernah dulu tuh, maksudnya baik-baik aja terus aku tanyain kenapa dia juga ga jawab. Jadi lebih banyak kesepiannya sih aku tuh." (Interpersonal Relation)

"Ya takutnya kalo misalnya aku ngobrol sama mereka, merekanya terganggu gitu." (Irrational Thought)

Pada sebagian besar wawancara yang dilakukan, subjek mengeluhkan masalah hubungan interpersonal seperti dijauhi teman-teman dan sahabatnya, diperlakukan buruk oleh keluarganya, dan tidak adanya orang dekat seperti pacar. Oleh karenanya, subjek merasa kesepian yang membuatnya semakin terbebani. Dalam konteks lingkungan sosial, subjek mengaku bahwa dirinya ditinggalkan oleh teman-teman dan sahabatnya yang menurutnya tidak mau berteman dengan subjek lagi. Bahkan subjek tidak berani memulai pembicaraan karena merasa mereka akan terganggu ketika diajak mengobrol. Hal ini merupakan bagian dari irrational thought subjek.

Dalam konteks keluarga, komunikasi tidak berjalan dengan baik. Masing-masing anggota keluarga jarang berinteraksi satu sama lain, kecuali antara subjek dengan adiknya. Terkait dengan orang tua, subjek diperlakukan buruk secara verbal oleh ayah, sekaligus kakaknya. Subjek sering diusir dan dimarahi ketika subjek masuk ke kamar ayah hanya karena ingin berbicara atau bertemu ayahnya. Begitupun dengan kakaknya yang memarahi subjek seperti yang tergambar pada kalimat di bawah ini:

"Ya hampir ga pernah ngobrol sih, paling kalo habis makan bareng gitu udah aja ke kamar masing-masing, kembali ke kerjaan masing-masing. Waktu makan itu itu ga ngobrol." (Bad Communication)

"Kalo sama kakak enggak sama sekali. Bener-bener ga akrab mah. Setiap aku deketin pasti dia marah-marah, teriak gitu. Bahkan ada satu periode setahun lebih aku bener-bener ga ngomong banget sama dia padahal tinggal di satu rumah yang sama. (Sibling Relation) 
"Deketin maksudnya kayak aku samperin gitu, kayak misalnya dia lagi nonton tv terus aku ikut nonton juga dia pasti marah. Apa-apa tuh marah gitu. Aku bener-bener menghindar dari orang kayak gitu." (Sibling Relation)

"Kalo mama enggak, papa iya. Tiap aku datengin selalu bilang udah pergi aja jangan ganggu." (Parent)

Perlakuan - perlakuan tersebut mungkin menjadi latar belakang munculnya irrational thought mengenai teman-teman subjek.

\section{Nonsuicidal Self Injury (NSSI)}

Ketika subjek pertama mengiris bagian tubuh sebagai bentuk NSSI, subjek kedua menggunakan tiga bentuk NSSI. Yang pertama adalah memukul benda di sekitarnya. Subjek memaknai ekspresi agresi tersebut sebagai tindakan self-harm. Yang kedua, subjek membiarkan diri kelaparan dengan tidak makan selama beberapa hari. Yang terakhir, subjek mengiris bagian tubuhnya dengan benda tajam. Ketiga bentuk NSSI tersebut diakui oleh subjek pada semua jawaban ini:

"Itu mukul kan juga salah satunya. Terus ngebiarin diri kelaparan. Bahkan pernah paling lama tuh berhari-hari aku ga makan, 3 hari mungkin." (NSSI)

"Dulu pernah nyilet diri sendiri gitu, di tangan. Cuma semenjak cutter disingkirin dari kamar, udah ga pernah lagi." (NSSI)

\section{Suicidal Action}

"(menghela nafas panjang sambil menangis dan tidak berbicara cukup lama).......... Gantung diri (menangis dan tidak berbicara cukup lama)." (Suicidal Action)

Subjek kedua tidak hanya berhenti sampai suicidal ideation seperti pada subjek pertama. Ideation tersebut sudah pernah direalisasikan oleh subjek dengan cara gantung diri di kamar meskipun pada akhirnya gagal. Subjek menangis ketika hendak membahas hal ini dan enggan untuk bercerita lebih jauh.

\section{Gambaran Regulasi Emosi}

\section{Strategies (S)}

Subjek sebenarnya memiliki beberapa cara untuk membuat perasaannya menjadi lebih baik, yaitu bermain game online dan mendengarkan musik. Namun seiring berjalannya waktu, dengan bertambahnya stressor di sekitar subjek, cara tersebut ternyata semakin tidak memberikan efek apapun pada perasaannya. Dengan kata lain, muncul intoleransi pada mekanisme coping yang sudah biasa ia lakukan.

Intoleransi tersebut akhirnya berakibat pada munculnya ekspresi agresi yang seolah tidak dapat dibendung lagi oleh subjek sebagaimana yang terlihat pada kalimat subjek berikut ini:

"Ga ada sih. Tapi dulu tuh bisa misalnya dibuat main game, denger musik, bisa ngilangin. Tapi ga tau kenapa sekarang ga mempan." (Activity Intolerance)

"Ga tau sih tepatnya kapan, pokoknya waktu awal-awal kuliah itu pas ngerasa sendiri, ga ada temen, terus nilai jelek terus gitu. Mulai saat itu ngerasa hiburan itu udah ga guna, udah ga bisa nenangin diri gitu. Mukul-mukul barang." (Loneliness dan Aggressive Expression) 
Dari pernyataan pada baris 50, dapat diidentifikasi stressor yang menambah beban subjek adalah kesepian. Perihal kesepian pada subjek ini, akan dibahas di bagian gambaran depresi.

\section{Impulse (I)}

"Misalnya kalo aku marah kan aku mukul benda yang deket bisa meja. Terus juga suka mikir mendingan aku mati aja gitu. Itu kalo marahnya banget." (Agression \& Death Wish)

Seperti yang sudah dijelaskan di atas, subjek cenderung tidak mampu untuk mengontrol impuls ketika merasakan emosi negatif. Impuls tersebut dikeluarkan dalam bentuk agresi yakni memukul barang atau benda yang ada di sekitarnya. Seringkali, ekspresi agresi tersebut diiringi dengan tangisan. Namun subjek tidak melakukan ekspresi tersebut ketika berada di tempat umum kecuali dorongan dalam diri untuk mengeluarkan agresivitas dalam dirinya tidak tertahankan lagi.

\section{Goals (G)}

"Susah fokus biasanya. Kayak misalnya waktu itu pernah ikut kepanitiaan. Bener-bener di tengah dan nanganin pendaftaran baru. Terus ga ada apa-apa tiba-tiba aku marah aja. Disitu aku ijin ke kamar mandi. Akhirnya nangis sama marah sendiri sambil ngepalin tangan sampe kulit luka. Kuku jari saking kuatnya kepalan tangan. Karena aku agak lama, sekitar sejam lebih ijinnya, akhirnya tugasku dikerjain sama temen-temen yang lain karena pas aku keluar dari kamar mandi udah pada selesai semua kegiatannya." (Helplessness)

Pada dimensi ini, subjek tidak memiliki tujuan jangka panjang maupun pendek. Subjek juga cenderung mengabaikan tugas dan tanggung jawabnya dan berfokus pada ekspresi emosi yang dirasakan untuk membuatnya merasa lebih baik ketika sedang terlibat dalam kelompok belajar atau kegiatan. Akibatnya, semua tugas dan tanggung jawab subjek diambil alih dan ditangani oleh teman-temannya yang lain.

\section{Awareness (A), Clarity (C), dan Nonacceptance (N)}

"Misalnya kalo aku marah kan aku mukul benda yang deket bisa meja. Terus juga suka mikir mendingan aku mati aja gitu. Itu kalo marahnya banget." (Death Wish)

"Ga tau sih, kadang kalo lagi emosi tuh suka random gitu lho. Misalkan aku lagi nggak ngapa-ngapain gitu ya, lagi gabut, bisa bener-bener bisa marah, aku ga tau kenapa.” (No Idea of Causality)

"Jadi waktu itu aku tuh bener-bener pengen cepet pulang biar bisa nangis di kamar atau teriak atau mukul-mukul lagi. Kan aku tetep malu gitu kalo ngelakuin itu di depan umum." (Ashamed)

"Langsung aja itu mukul meja restoran, meja cafe. Dan distraksi gitu orang jadi ngeliatin kan. Aku jadi malu, dan langsung pergi dari situ.” (Aggression \& Ashamed)

“......Kayaknya engga deh, ga bisa, kayak udah mixing gitu. Jadi ga bisa dibedain mana yang dominan." (Incapability to Differenciate)

Pada semua pernyataan di atas, dapat dikatakan bahwa subjek tidak mampu melakukan identifikasi emosi yang dirasakan ketika sedang dalam situasi emosional meskipun ia mengerti perbedaan emosi negatif secara konseptual. Subjek juga tidak mengerti apa yang membuatnya merasakan emosi negatif dan sering tiba-tiba marah tanpa adanya penyebab yang jelas. Hal ini membuatnya terbebani dan bahkan memikirkan kematian sebagai satu kondisi yang lebih baik (death wish). Selain itu, subjek seringkali malu ketika dirinya bertindak agresi di tempat umum 
dengan memukul benda disekitarnya sebagai akibat dari ketidakmampuannya menahan agresivitas.

\section{DISKUSI}

Penelitian ini bertujuan untuk mendapatkan gambaran pada apa yang membuat penderita depresi tidak sulit meregulasi emosinya dengan cara melakukan perbandingan dengan individu depresi yang sulit meregulasi emosi. Perbedaan mendasar dalam dimensi kesulitan regulasi emosi antara subjek pertama (AA) dan kedua (A) adalah mekanisme regulasi emosi. Pada AA, terdapat mekanisme yang terstruktur untuk menanggulangi emosi negatif yang dirasakan. Relaksasi yang dilakukan oleh AA akan memberikan efek mindful dimana kondisi ini akan membuat regulasi emosi menjadi lebih mudah (Nyklíček, Zeelenberg, \& Vingerhoets, 2011; Menezes, Pereira, \& Bizarro, 2012; Ostafin, Robinson, \& Meier, 2015; Tang, Tang, \& Posner, 2016). Kemudian secara tidak langsung AA melakukan prinsip CBT dan terapi berbasis acceptance ketika berusaha berpikir logis dan berfokus pada solusi. Penerapan prinsip kedua terapi tersebut dapat secara signifikan meningkatkan kemampuan regulasi emosi (Gratz, Weiss, \& Tull, 2015) yang membuat impuls AA dapat terkontrol, tugas dan tanggung jawab tetap dapat dikerjakan dan diselesaikan, identifikasi emosi dapat dilakukan, penerimaan terhadap keadaan emosional yang dirasakan pun juga mampu diterapkan. Hal ini berbanding terbalik dengan A yang tidak memiliki mekanisme tersebut. Pada A, emosi dirasakan sedemikian rupa serta dilakukan supresi sesaat untuk kemudian melakukan ekspresi agresi. Padahal, mekanisme regulasi emosi yang berfokus pada perilaku agresi akan semakin meningkatkan frekuensi dan intensitas perilaku agresi itu sendiri (Roberton, Daffern, \& Bucks, 2012).

Depresi yang dirasakan oleh subjek AA lebih disebabkan oleh orientasi seksual lesbian dimana ia mendapatkan perlakuan dan pandangan negatif dari orang-orang sekitar, termasuk keluarganya. Dampak dari depresi yang dirasakan oleh AA adalah munculnya tindakan NSSI dan suicidal ideation yang terjadi hampir setiap waktu dan hampir pada setiap situasi. Dampak tersebut sesuai dengan beberapa penelitian yang menyatakan bahwa individu dengan orientasi seksual lesbian memang terbukti lebih rentan mengalami suicidal ideation, bahkan suicidal attempt dibandingkan mereka yang heteroseksual ( Silenzio, Pena, Duberstein, Cerel, \& Knox, 2007; King, Semlyen, Tai, Killaspy, Osborn, Popelyuk, \& Nazareth, 2008; Baams, Grossman, \& Russell, 2015). Sedangkan pada A, depresi disebabkan oleh hubungan interpersonal dalam lingkungan sosial dan keluarga yang berakibat pada rasa kesepian. Kurangnya komunikasi dan interaksi dengan keluarga serta perlakuan keluarga yang tidak menyenangkan juga berkontribusi dalam membentuk irrational thought (David, Lynn, Ellis, \& Wilson, 2009) mengenai inisiasi percakapan dalam lingkungan sosial, sehingga membuat A menjadi semakin terisolasi oleh diri sendiri.

Jika kedua gambaran depresi pada AA dan A dibandingkan, maka perbedaan yang mencolok pada keduanya adalah penyebab dan efek dari penyebab tersebut. A tidak memiliki significant others untuk membagikan dan mengekspresikan perasaannya secara adaptif. Sedangkan AA tidak memiliki masalah interpersonal semacam itu. Bahkan AA mengikuti komunitas LGBT yang sering mengadakan pertemuan untuk saling sharing. Disini, komunitas yang diikuti oleh AA tersebut dapat menjadi suatu bentuk terapi kelompok yang dapat mengurangi gejala depresi. Dalam penelitian yang dilakukan oleh Seligman, Schulman, dan Tryon (2007), terapi kelompok terbukti mampu mencegah gejala depresi dan kecemasan berkembang menjadi gejala yang lebih serius. Terlebih jika terapi kelompok menyisipkan konsep CBT di dalam pelaksanaannya serta dilakukan secara rutin, tingkat keparahan depresi dapat menurun secara signifikan (Thimm \& Antonsen, 2014). Oleh karena itu, komunitas yang diikuti AA bisa menjadi suatu kegiatan yang membuat gejala depresi berkurang, bahkan tingkat keparahannya dapat dimungkinkan menurun. AA juga memiliki pacar sejenis yang menjadi 
salah satu significant others nya. Keberadaan significant others cukup memberikan dampak positif terhadap kondisi depresi yang dialami (Marroquín, 2011). Depresi yang disebabkan oleh hubungan interpersonal akan berdampak lebih buruk daripada depresi yang disebabkan oleh konflik intrapersonal (Flynn \& Rudolph, 2011; Majd Ara, Talepasand, \& Rezaei, 2017). Hal ini cukup menjelaskan mengapa AA tidak kesulitan meregulasi emosi dibandingkan dengan A. Hasil penelitian ini tampaknya didukung dengan studi Eftekhari, Zoellner, dan Vigil (2009) yang menduga kapasitas dan fleksibilitas dalam menerapkan strategi regulasi emosi berdasarkan konteks dan waktu mungkin dapat membantu menyematkan fungsi-fungsi yang lebih adaptif pada individu yang mengalami kondisi psikopatologi, termasuk depresi. Pada AA, kapasitas meregulasi emosi terlihat jelas dengan diterapkannya mekanisme yang sudah disebutkan di atas. AA juga fleksibel dalam menerapkan strategi ketika mendapati situasi yang tidak menyenangkan yaitu mengandalkan interpersonal support.

Di lain sisi, hasil ini bertolak belakang dengan studi yang dilakukan oleh James, Gross, dan Jazaieri (2014) yang menyatakan bahwa emotion dysregulation dengan tiga dimensi yang berkontribusi pada emotion dysregulation yaitu awareness, goals, dan strategi, berkaitan erat dengan kondisi psikopatologis, termasuk depresi itu sendiri. Joormann \& Gotlib, (2010) dan Joormann dan Stanton (2016) juga menyatakan hal serupa yang menitikberatkan pada aspek kognitif. Sejalan dengan itu, Rajappa, Gallagher, dan Miranda (2012) dan Werner-Seidler, Banks, Dunn, dan Moulds (2013) mengemukakan bahwa kesulitan regulasi emosi berasosiasi erat dengan pemikiran dan tindakan bunuh diri yang merupakan gejala utama depresi. Tetapi jika dilihat lebih dalam, perbedaan ini dikarenakan semua studi tersebut berorientasi pada framework regulasi emosi mempengaruhi kondisi depresi, bukan sebaliknya. Dengan kata lain, dinamika kondisi depresi yang terjadi pada masing-masing subjek penelitian kurang diperdalam. Padahal sejatinya gangguan psikologi itu unik. Meskipun dua orang memiliki diagnosis gangguan yang sama, belum tentu dinamika masalahnya juga sama. Bahkan James J, Gross dan Jazaieri (2014) mengakui jika dibutuhkan penelitian lebih lanjut untuk mengetahui disparasi yang terjadi antara disregulasi emosi dan depresi.

\section{KESIMPULAN}

Pada subjek pertama (AA), didapatkan temuan signifikan pada dimensi strategi (S) yang berkaitan dengan dimensi impulse (I). Goals (G) yang dimiliki belum jelas. Lalu sisanya $(\mathrm{A}, \mathrm{N}, \mathrm{C})$ berdinamika menjadi satu yang mengindikasikan adanya penerimaan subjek terhadap emosi negatif. Sedangkan pada subjek kedua (A), ditemukan adanya beberapa perbedaan yang cukup signifikan baik pada gambaran regulasi emosi dan gambaran depresi. Dari segi kesulitan regulasi emosi, aspek aggressive expression adalah yang paling banyak muncul dalam dimensi impulse dan strategies. Pada dimensi ACN, didapatkan aspek death wish, incapability to differentiate emotion, no idea of causality, dan ashamed. Sedangkan dimensi goals, hanya berfokus pada aspek helplessness. Depresi yang dialami oleh A cenderung menitikberatkan pada faktor interpersonal yang menyebabkan kondisi intrapsikis terganggu dimana faktor tersebut menjadi kunci dari sulit atau tidaknya seseorang meregulasi emosi. Penyebab depresi yang lebih ditekankan pada konflik intrapersonal tanpa adanya masalah pada aspek interpersonal, membuat AA menjadi lebih mudah meregulasi emosinya. Hal ini diperkuat dengan adanya mekanisme regulasi emosi yang menerapkan prinsip CBT dan terapi berbasis acceptance. Selain itu, adanya significant others dan keikutsertaan AA dalam kegiatan yang menciptakan efek terapeutik semakin berkontribusi untuk memudahkannya meregulasi emosi dengan mengurangi tingkat keparahan gejala depresi. 


\section{UCAPAN TERIMA KASIH}

Terima kasih peneliti ucapkan kepada Dr. Fitri Ariyani Abidin, M.Psi, Psikolog yang terus berusaha memberi semangat pada peneliti dan rekan mahasiswa lain untuk segera menyelesaikan studi. Tidak lupa juga peneliti berterima kasih kepada Dr. Retno Hanggarani Ninin, M.Psi, Psikolog yang telah bersedia memberikan saran dan masukan terhadap penelitian ini. Terakhir, peneliti mengucapkan banyak terima kasih kepada LPDP Kementrian Keuangan RI yang memberikan pendanaan penuh terhadap studi peneliti dan tidak lelah berjuang memajukan bangsa dengan menciptakan generasi emas di masa depan melalui pendidikan.

\section{DAFTAR PUSTAKA}

Angell, D. (2017). Emotion regulation in depression, anxiety and stress: a focus on catastrophising. (December). Retrieved from http://centaur.reading.ac.uk/73484/

Baams, L., Grossman, A. H., \& Russell, S. T. (2015). Minority stress and mechanisms of risk for depression and suicidal ideation among lesbian, gay, and bisexual youth. Developmental Psychology, 51(5), 688-696. https://doi.org/10.1037/a0038994

Badan Penelitian dan Pengembangan Kesehatan. (2013). Riset Kesehatan Dasar (RISKESDAS) 2013. Laporan Nasional 2013. https://doi.org/1 Desember 2013

Compare, A., Zarbo, C., Shonin, E., Van Gordon, W., \& Marconi, C. (2014). Emotional Regulation and Depression: A Potential Mediator between Heart and Mind. Cardiovascular Psychiatry and Neurology, 2014, 1-10. https://doi.org/10.1155/2014/324374

David, D., Lynn, S., Ellis, A., \& Wilson, D. S. (2009). Rational and Irrational Beliefs from an Evolutionary Perspective. In Rational and Irrational Beliefs. https://doi.org/10.1093/acprof:oso/9780195182231.003.0004

Eftekhari, A., Zoellner, L. A., \& Vigil, S. A. (2009). Patterns of emotion regulation and psychopathology. Anxiety, Stress and Coping, 22(5), 571-586. https://doi.org/10.1080/10615800802179860

Ehring, T., Tuschen-Caffier, B., Schnülle, J., Fischer, S., \& Gross, J. J. (2010). Emotion regulation and vulnerability to depression: Spontaneous versus instructed use of emotion suppression and reappraisal. Emotion, 10(4), 563-572. https://doi.org/10.1037/a0019010

Flynn, M., \& Rudolph, K. D. (2011). Stress generation and adolescent depression: Contribution of interpersonal stress responses. Journal of Abnormal Child Psychology, 39(8), 1187-1198. https://doi.org/10.1007/s10802-011-9527-1

Gratz, K. L., \& Roemer, L. (2004). Multidimensional Assessment of Emotion Regulation and Dysregulation: Development, Factor Structure, and Initial Validation of the Difficulties in Emotion Regulation Scale. Journal of Psychopathology and Behavioral Assessment, 26(1), 4154. https://doi.org/10.1023/B:JOBA.0000007455.08539.94

Gratz, K. L., Weiss, N. H., \& Tull, M. T. (2015). Examining emotion regulation as an outcome, mechanism, or target of psychological treatments. Current Opinion in Psychology, 3, 85-90. https://doi.org/10.1016/j.copsyc.2015.02.010

Gross, J. J. (2014). Handbook of emotion regulation (2nd ed.). New York, NY, US: Guilford Press.

Gross, James J., \& Jazaieri, H. (2014). Emotion, emotion regulation, and psychopathology: an affective science perspective. Clinical Psychological Science, 2(4), 387-401. https://doi.org/10.1177/2167702614536164

Joormann, J., \& Gotlib, I. H. (2010). Emotion regulation in depression: Relation to cognitive inhibition. Cognition and Emotion, 24(2), 281-298. https://doi.org/10.1080/02699930903407948

Joormann, J., \& Stanton, C. H. (2016). Examining emotion regulation in depression: A review and future directions. Behaviour Research and Therapy, 86, 35-49. https://doi.org/10.1016/j.brat.2016.07.007

Kalia, M. (2005). Neurobiological basis of depression: An update. Metabolism: Clinical and Experimental, 54(5 SUPPL.), 24-27. https://doi.org/10.1016/j.metabol.2005.01.009

King, M., Semlyen, J., Tai, S. S., Killaspy, H., Osborn, D., Popelyuk, D., \& Nazareth, I. (2008). A systematic review of mental disorder, suicide, and deliberate self harm in lesbian, gay and bisexual people. BMC Psychiatry, 8, 1-17. https://doi.org/10.1186/1471-244X-8-70 
LeMoult, J., \& Gotlib, I. H. (2018). Depression: A cognitive perspective. Clinical Psychology Review, (June). https://doi.org/10.1016/j.cpr.2018.06.008

Leppänen, J. M. (2006). Emotional information processing in mood disorders. Current Opinion in Psychiatry, 19(1), 34-39.

Lindsay, S. (2019a). Exploring the value of qualitative comparison groups in rehabilitation research: Lessons from youth with disabilities transitioning into work.

Lindsay, S. (2019b). Five Approaches to Qualitative Comparison Groups in Health Research: A Scoping Review. Qualitative Health Research, 29(3), 455-468. https://doi.org/10.1177/1049732318807208

Loeffler, L. A. K., Radke, S., Habel, U., Ciric, R., Satterthwaite, T. D., Schneider, F., \& Derntl, B. (2018). The regulation of positive and negative emotions through instructed causal attributions in lifetime depression - A functional magnetic resonance imaging study. NeuroImage: Clinical, 20(October), 1233-1245. https://doi.org/10.1016/j.nicl.2018.10.025

Majd Ara, E., Talepasand, S., \& Rezaei, A. M. (2017). A structural model of depression based on interpersonal relationships: The mediating role of coping strategies and loneliness. Noropsikiyatri Arsivi, 54(2), 125-130. https://doi.org/10.5152/npa.2017.12711

Marroquín, B. (2011). Interpersonal emotion regulation as a mechanism of social support in depression. Clinical Psychology Review, 31(8), 1276-1290. https://doi.org/10.1016/j.cpr.2011.09.005

Menezes, C. B., Pereira, M. G., \& Bizarro, L. (2012). Sitting and silent meditation as a strategy to study emotion regulation. Psychology and Neuroscience, 5(1), 27-36. https://doi.org/10.3922/j.psns.2012.1.05

Millgram, Y., Joormann, J., Huppert, J. D., \& Tamir, M. (2015). Sad as a Matter of Choice? EmotionRegulation Goals in Depression. Psychological Science, 26(8), 1216-1228. https://doi.org/10.1177/0956797615583295

Nyklíček, I., Zeelenberg, M., \& Vingerhoets, A. (2011). Emotion regulation and well-being. Emotion Regulation and Well-Being, 1-331. https://doi.org/10.1007/978-1-4419-6953-8

Ostafin, B. D., Robinson, M. D., \& Meier, B. P. (2015). Handbook of mindfulness and self-regulation. Handbook of Mindfulness and Self-Regulation, 1-301. https://doi.org/10.1007/978-1-4939-22635

Rajappa, K., Gallagher, M., \& Miranda, R. (2012). Emotion dysregulation and vulnerability to suicidal ideation and attempts. Cognitive Therapy and Research, 36(6), 833-839. https://doi.org/10.1007/s10608-011-9419-2

Roberton, T., Daffern, M., \& Bucks, R. S. (2012). Emotion regulation and aggression. Aggression and Violent Behavior, 17(1), 72-82. https://doi.org/10.1016/j.avb.2011.09.006

Seligman, M. E. P., Schulman, P., \& Tryon, A. M. (2007). Group prevention of depression and anxiety symptoms. Behaviour Research and Therapy, 45(6), 1111-1126. https://doi.org/10.1016/j.brat.2006.09.010

Silenzio, V. M. B., Pena, J. B., Duberstein, P. R., Cerel, J., \& Knox, K. L. (2007). Sexual orientation and risk factors for suicidal ideation and suicide attempts among adolescents and young adults. American Journal of Public Health, 97(11), 2017-2019. https://doi.org/10.2105/AJPH.2006.095943

Tang, Y. Y., Tang, R., \& Posner, M. I. (2016). Mindfulness meditation improves emotion regulation and reduces drug abuse. Drug and Alcohol Dependence, 163, S13-S18. https://doi.org/10.1016/j.drugalcdep.2015.11.041

Thimm, J.C. \& Antonsen, L. (2014). Effectiveness of cognitive behavioral group therapy for depression in routine practice. BMC Psychiatry. 14(1):292

Troy, A. S., Shallcross, A. J., \& Mauss, I. B. (2013). A Person-by-Situation Approach to Emotion Regulation: Cognitive Reappraisal Can Either Help or Hurt, Depending on the Context. Psychological Science, 24(12), 2505-2514. https://doi.org/10.1177/0956797613496434

Werner-Seidler, A., Banks, R., Dunn, B. D., \& Moulds, M. L. (2013). An investigation of the relationship between positive affect regulation and depression. Behaviour Research and Therapy, 51(1), 46-56. https://doi.org/10.1016/j.brat.2012.11.001

Whitmer, A. J., \& Gotlib, I. H. (2012). Switching and backward inhibition in major depressive disorder: The role of rumination. Journal of Abnormal Psychology, 121(3), 570-578. https://doi.org/10.1037/a0027474 
Williams, J. M. G., Crane, C., Barnhofer, T., Van der Does, A. J. W., \& Segal, Z. V. (2006). Recurrence of suicidal ideation across depressive episodes. Journal of Affective Disorders, 91(2-3), 189-194. https://doi.org/10.1016/j.jad.2006.01.002

World Health Organisation. (2017). Depression and other common mental disorders: global health estimates. World Health Organization.

Yin, R. K. (2018). Case study research and applications: Design and methods. Sixth Edition. Los Angeles: SAGE Publications 